\title{
SIMULATION MODEL DECOMPOSITION BY FACTOR ANALYSIS
}

\author{
Kenneth W. Bauer \\ Bipin Kochar \\ Joseph J. Talavage \\ School of Industrial Englneering \\ Purdue Unlversity \\ West Lafayette, Indlana 47907.
}

\begin{abstract}
This paper offers a solution to the simulation model decomposition problem discussed brlefly in Overstreet and Nance [1] and elaborated in detall in Overstreet [2]. The solution scheme Involves the use of princlpal components analysis. We offer an example of the technlque on a simple dlrected graph and then demonstrate the method on a small model given in Overstreet [2].
\end{abstract}

\section{INTRODUCTION}

In moving toward a model development environment for discrete event simulation, Overstreet and Nance [1] have advanced a model speclfication language to systematically brldge the gap between a conceptual model and an executable representation of that model. In dolng so, they introduce a formallsm based on a condition speciflcation. They demonstrate contrlbutions of thelr model speciflcation language to slmulation theory and polnt out the utility of the formallsm in an implementation enviroment.

One important area of application is the decomposition of models. Simply put, given a model speclflcation, how to systematically decompose this representation into possible submodels? If a large model speclflcation can be decomposed into submodels, this would facllitate model implementation because the task could be divided between programming groups. Overstreet [2] puts forth a framework for model decomposition, using a Cluster Interaction Graph. This directed graph represents a condition speclfication by nodes in a graph. The nodes represent "action clusters" constructed with the primltives of the specification language. These action clusters are llnked through attributes. Attributes characterize objects in the model, and a change of an attribute in one cluster can trigger the actions of another cluster. Say for example, in a model speclflcation of a machlne shop, a machlne falls in an action cluster. The fallure is reflected as an attribute change and this in turn triggers the activities of another cluster. In this fashlon, Overstreet links model actions to model attributes. He reasons that a link exlsts between action clusters when an output attribute for one cluster serves as an input/control attrlbute for another cluster. Further, action clusters with a high degree of interaction ought to be in the same component of the model. Now, within the Cluster Interaction Graph thls "flow" of Information between the nodes is represented by arcs. Overstreet suggests that the graph can be decomposed Into two minlmallv interactive submodels by partitioning the graph
Into a palr of nonempty subgraphs with a minlmal number of arcs connectlng them. This problem has a complexity of $2^{N}$ (where $N$ is the number of nodes). Another unfortunate feature of thls cutset approach is that it offers no stopplng rule.

We propose a solution to this problem which is not of high order complexity and has a bullt-ln stopping rule. The Cluster Interaction Graph is reformulated Into an assoclation matrix and a factor analytic method is applied to the matrlx. Thls technlque is simllar to that found in Garrison and Marble [3]; thelr research dealt with transportation networks. Another application of this technlque is found in McClain [4].

The association matrlx entries represent the strength of relationshlps between the nodes. It is based on the number and direction of attributes they share. The eigenvalues and assoclated elgenvectors are extracted from the association matrix and then rotated to a solution best exhibiting the "simple structure" (in the sense of Thurstone (Indirectly referenced through McNichols [5]) the model may exhiblt.

We show an example of the technlque on a simple directed graph and then demonstrate the method on an example from Overstreet [2].

\section{A SIMPLE EXAMPLE}

Conslder the following simple directed graph.

Flgure 1. SImple Graph

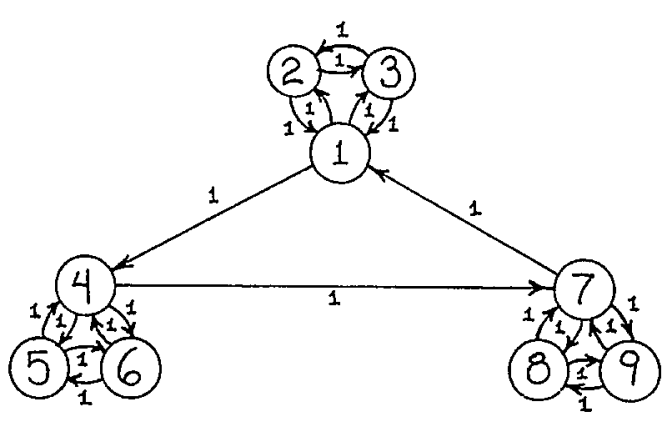


Assume that the numbers assigned to the arcs represent the amount and direction of information that is shared between nodes. Visually assessing this graph, one sees that there are basically three subgraphs. Nodes 1,2 , and 3 form a logical subgraph, as do nodes 3,4, and 5, as well as nodes 8,7 , and 8.

We may construct an edge-incldence matrix $E$ as follows. If node 1 communicates with node $j$, then $E$ can be constructed by

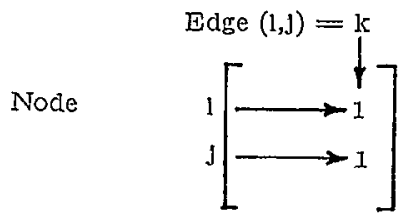

Next construct the matrix $A=E W W^{T} E^{T}$, where $W$ is a weightlng matrlx. Various welghtlng schemes are possible. For instance, it might be reasonable to welght the bldirectlonal arcs more heavlly than unldlrectional arcs.

Now A Is symmmetrlc and positive seml-deflnite, hence it can be converted to an association (pseudo-correlation) matrlx by multlplying it by the matrix $D$, where

$$
\mathrm{D}=\left[\begin{array}{llll}
\ddots & & & \\
\ddots & 1 / \sqrt{\mathrm{a}_{\mathrm{ii}}} & & \\
& & \ddots & \\
& & & \ddots
\end{array}\right]
$$

Now we have $\mathrm{C}=\mathrm{D}^{\mathrm{T}} \mathrm{AD}$. The elgenvalues and associated eigenvectors are extracted from this matrix. The elgenvalues can be examined to see if a potential reduction in dimensionallty is reasible. Based on thls examination certaln factors (scaled and normalized elgenvectors) are retalned and these are rotated to simple structure.

Thls procedure was accomplished for the graph in Figure 1. Princlpal components analysis was performed using SPSS. Princlpal components analysis is equivalent to the elgenvalue analysis descrlbed above.

Table 1 detalls the factors and associated elgenvalues as extracted from the pseudo-correlation matrlx prepared for the graph presented in Figure 1 .

\begin{tabular}{|cccc|}
\hline \multicolumn{4}{c|}{ Table 1. Extracted Factors } \\
\hline \hline Factor & Elgenvalue & Pct. of Var & Cum. Pct \\
1 & 2.00000 & 22.2 & 22.2 \\
2 & 1.83333 & 20.4 & 42.6 \\
3 & 1.83333 & 20.4 & 83.0 \\
4 & .83333 & 9.3 & 72.2 \\
5 & .50000 & 5.8 & 77.8 \\
6 & .50000 & 5.6 & 83.3 \\
7 & .50000 & 5.6 & 88.8 \\
8 & .50000 & 5.6 & 94.4 \\
9 & .50000 & 5.6 & 100.0 \\
\hline
\end{tabular}

Notice that $83 \%$ of the variance in thls graph is explained by 3 factors. Also notlce that the fourth elgenvalue is less than 1 . Retalning only those factors whose elgenvalues are at least 1 is a popular retention crlterla attributed to Kalser [6]. Some empirical evidence for the use of this criterla is offered by Bauer [7]. Table 2 is a table of initial factor loadings. This table relates the nodes to the factors, the hlgher the loading the greater the linear correlation to the factor.

\begin{tabular}{|cccc|}
\hline \multicolumn{4}{c|}{ Table 2. Inltlal Factor Loadings } \\
\hline \hline Node & Factor 1 & Factor 2 & Factor 3 \\
Node1 & .53452 & -.51044 & .21215 \\
Node2 & .43644 & -.62516 & .25983 \\
Node3 & .43644 & -.02516 & .25083 \\
Node4 & .53452 & .43895 & .33598 \\
Node5 & .43644 & .53760 & .41148 \\
Node6 & .43644 & .53700 & .41149 \\
Node7 & .53452 & .07149 & -.54813 \\
Node8 & .43644 & .08765 & -.67132 \\
Node9 & .43644 & .08765 & -.87132 \\
\hline
\end{tabular}

Since the first extracted factor tends to be a general factor (see Nle [8]), relating all the varlables to one another, not much is gleaned from thls Initlal factor loadings matrix. Application of varimax rotation to this matrix ylelds much more interesting results. Table 3 is the new rotated factor matrlx.

\begin{tabular}{|cccc|}
\hline \multicolumn{4}{|c|}{ Table 3. Rotated Factor Matrix } \\
\hline \hline Node & Factor 1 & Factor 2 & Factor 3 \\
Node1 & .08294 & .08294 & .75904 \\
Node2 & -.02441 & -.02441 & .80475 \\
Node3 & -.02441 & -.02441 & .80475 \\
Node4 & .75994 & .08294 & .08284 \\
Node5 & .80475 & -.02441 & -.02441 \\
Node6 & .80475 & -.02441 & -.02441 \\
Node7 & .08294 & .75994 & .08294 \\
Node8 & -.02441 & .80475 & -.02441 \\
Node8 & -.02441 & .80475 & -.02441 \\
\hline
\end{tabular}

Before addressing this matrix we refer back to Table 1 . Note that by Kalser's criterlon we retained 3 factors. Now, looking at Table 3 , we note that 3 nodes load heavlly on each factor (clrcled). Hence, we summarize by saylng that there seems to be 3 princlpal subgraphs here 3 retalned factors) and each is composed of the 3 nodes indicated.

\section{DECOMPOSITION OF A CONDITION SPECIFI- CATION}

To demonstrate the method's potentlal in model decomposition, we apply it to a Cluster Interaction Graph of a harbor simulation model offered by Overstreet [2]. The harbor model has shlps arriving at a harbor. These ships walt in an area just outside the harbor untll a tug is avallable to move them to thelr assigned berth. Once the shlps are unloaded and a tug is avallable, the ships are moved out of the harbor. Overstreet presents a condition speclfication 
Simulation Model Decomposition by Factor Analysis

\begin{tabular}{|c|c|c|c|c|c|c|c|c|c|c|c|c|}
\hline \multicolumn{13}{|c|}{$\begin{array}{c}\text { Table 4. Cluster Interaction Graph } \\
\text { (From Overstreet [2]) }\end{array}$} \\
\hline \multirow[t]{7}{*}{ Clusters } & & a & & & e & $d$ & $\mathrm{e}$ & & & & & \\
\hline & & $\Gamma$ & & $u$ & $\mathrm{n}$ & e & $\mathrm{n}$ & & & & & \\
\hline & & $\mathbf{r}$ & e & $\mathrm{n}$ & d & b & d & & & & & \\
\hline & 1 & 1 & $\mathrm{n}$ & 1 & & e & & $\mathrm{m}$ & $t$ & $\mathrm{~m}$ & $t$ & $\mathrm{t}$ \\
\hline & $\mathrm{n}$ & $\mathrm{v}$ & $\mathrm{t}$ & 0 & $\mathrm{u}$ & $\mathrm{r}$ & d & $t$ & a & $\mathrm{t}$ & a & $\mathrm{e}$ \\
\hline & 1 & a & e & a & $\mathrm{n}$ & $\mathrm{t}$ & e & $t$ & a & $\mathrm{t}$ & a & $\mathbf{r}$ \\
\hline & $t$ & 1 & $r$ & $\mathrm{~d}$ & 1 & h & $\mathrm{b}$ & $\mathrm{p}$ & $\mathrm{p}$ & 0 & O & $\mathrm{m}$ \\
\hline InItiallzation & & 1 & 3 & & & 4 & & 5 & & 4 & & \\
\hline arrival & & 1 & 1 & & & 1 & & 1 & & 1 & & \\
\hline enter & & & 2 & 1 & & 2 & & 3 & & 3 & & \\
\hline unload & & & & & 1 & 1 & & 1 & & 1 & & \\
\hline end unload & & & & & & 1 & & 1 & & & & \\
\hline deberth & & & 1 & & & 3 & 1 & 3 & & 2 & & \\
\hline end deberth & & & 1 & & & & & 1 & & 1 & & 1 \\
\hline move tug to pler & & & 1 & & & & & 1 & 1 & 1 & & \\
\hline tug arr at pler & & & & & & 1 & & 1 & & 1 & & \\
\hline move tug to ocean & & & & & & 1 & & 1 & & $I$ & 1 & \\
\hline $\begin{array}{l}\text { tug arr at ocean } \\
\text { termination }\end{array}$ & & & 1 & & & & & 1 & & 1 & & \\
\hline
\end{tabular}

for the harbor model based on 12 actlon clusters. He glves self-explanatory names to each cluster (node) and presents an arc-incldence matrlx which detalls the shared informatlon between the nodes. Table 4 is from Overstreet. We converted thls table to an assoclation matrix and factored It using SPSS. The flnal rotated factor loading matrix is Table 5.

\begin{tabular}{|c|ccccc|}
\hline \multicolumn{6}{|c|}{ Table 5. Harbor Model: Rotated Factor Matrlx } \\
\hline \multirow{2}{*}{ Node } & \multicolumn{5}{|c|}{ Factor } \\
\cline { 2 - 6 } & 1 & 2 & \multicolumn{1}{c|}{3} & \multicolumn{1}{c|}{4} & 5 \\
\hline taao & -.088 & -.0241 &. .868 & .011 & -.008 \\
arriv & -.014 & .048 & .001 & -.005 &. .026 \\
enter & .042 & -.068 & .228 & .593 & .314 \\
unload & .705 & -.001 & .077 & .061 & .019 \\
endunld & .791 & -.044 & .047 & -.082 & -.058 \\
deber & .412 & .250 & -.148 & .397 & .211 \\
enddeb & -.045 & .074 & -.026 &. .815 & -.215 \\
mttp & -.018 & .643 & .226 & .197 & .108 \\
taap & .009 & .868 & -.042 & -.108 & -.051 \\
mtto & .272 & .226 & .011 & .084 & .031 \\
\hline
\end{tabular}

Referring to Table 5 , first notice that 5 factors are retalned. Since we are factoring a 10 varlable set, we see that we may have trouble finding separable submodels since the overall model is so interrelated. However, a couple of observations are warranted. Notice that Unload and Endunld load heavlly on the first factor and that MTTP and TAAP score heavily on the second factor. Thls suggests that "pler actlvitles" and "harbor actlvlties" might represent reasonable submodels. Note also that TAAO and MTTO load heavily on the thlrd factor, perhaps indicating a submodel of "ocean actlvitles". It is interesting to note that the arrival of ships to the system loads on the fifth, independent factor.

\section{SUMMARY}

The use of factor analytic techniques, in particular the method of princlpal components, offers a low complexity solution to model decomposition problem. Cluster Interaction Graphs can be converted into assoclation matrices and these matrices can be factored using standard factor analysis routines such as those found in SPSS.

\section{REFERENCES}

[1] Overstreet, C. M. and Nance R. E. " A Speciflcation Language to Assist In Analysis of Discrete Event Slmulation Models," Communications of the ACM 2, February 1985, 180-201.

[2] Overstreet, C. M. " Model Speclfcation and Analysis for Discrete Event SImulation", Unpublished Doctoral Dissertation, VIrglnla Polytechnlc Institute and State Unlversity, 1082.

[3] Garrison, W. L. and Marble D. F. The Structure of Transportation Networks, TCREC Technlcal Report 62-11, Transportation Center, Northwestern University, Evanston, Illinols, May 1062.

[4] MeClaln, Denny R. "A Systems approach to the Aeromedical Alrcraft Routing Problem Using A Computer Based Model," Unpublished Doctoral Dissertation, Unlversity of Callfornla, Berkeley, December 1084.

[5] McNichols, Charles W. " An Introduction to Applled Multivariate Data Analysls ( Course Notes )," Alr Force Instltute of Technology, WPAFB, Ohlo, 1880.

[6] Talser, H. F. "The Appllcation of Electronlc Computers to Factor Analyss," Educational and Psychological Measurement, 20, 1960, 141-151. 
[7] Bauer, Kenneth W. " A Monte Carlo Study of Dimensionality Assessment and Factor Interpretation In Princlpal Components Analysis," Unpublished Master's Thesis, Air Force Institute of Technology, 1981.

[8] Nie, N. H. et. al. Statistical Package for the Social Sciences, 2nd Edition, New York: McGraw Hill, 1975.
KENNETH W. BAUER is a Captaln in the Unlted States Alr Force and currently a Ph.D. student in Industrlal Engineerlng at Purđue University.

Grissom Hall, Room 374

Purdue University

West Lafayette, Indlana 47907

(317) 484-1787

BIPIN KOCHAR holds a M.S. In Industrlal Englneering from Purdue Unlversity and is currently employed by Pritsker and Assoclates.

Grissom Hall, Room 374

Purdue UnIversity

West Lafayette, Indlana 47907

(317) 484-1797

JOSEPH J. TALAVAGE is a professor of Industrial Englneering at Purdue UnIversity. He holds a Ph.D. (Systems Englneering) from Case Institute of Technology, 1968. In addition to teaching simulation courses at the graduate level, he is engaged In research on slmulation methodology, Including the development of a manufacturing declsion support system, and the use of simulation to design Improved hlerarchlcal control systems for steel production. He has been a consultant to numerous companles and govermental agencles, and is the prime developer of the microNET sImulation language.

Room 1318C

Michael Golden Laboratorles

Purdue University

West Lafayette, Indlana 47907

(317) 494-5412 